\title{
Psoriasis vulgaris and familial cancer risk- a population-based study
}

\author{
Romuald Maleszka ${ }^{1}$, Katarzyna Paszkowska-Szczur², Ewa Soczawa' ${ }^{1}$, Magdalena Boer ${ }^{1}$, Monika Różewicka-Czabańska', \\ Joanna Wiśniewska ${ }^{1}$, Aneta Mirecka ${ }^{2}$, Lidia Krysztoforska ${ }^{3}$, Zygmunt Adamski ${ }^{4}$, Jan Lubinski ${ }^{2}$ and Tadeusz Dębniak ${ }^{2 *}$
}

\begin{abstract}
Background: Follow-up studies of psoriasis patients indicate an increased risk in the occurrence of malignancies at different sites of origin. Population stratification and/or complicated interpretation of evidence on the risk of cancer (due to the small number of patients included in most series) lead to inconsistent data. Herein we investigated the risk of occurrence of malignancies at different sites of origin in a series of 517 psoriasis patients and their 1st degree relatives.
\end{abstract}

Methods: We evaluated the tumour spectrum as well as the age of the patient at diagnosis of cancers in psoriasis families along with the observed and expected frequencies of malignancies. The distribution of 17 common mutations/polymorphisms in 10 known cancer susceptibility genes among psoriasis patients and 517 matched healthy controls were examined. No such study has been published to date.

Results: The statistical comparison of the observed and expected frequencies of cancers revealed a higher than expected occurrence of Hodgkin's lymphoma among males in psoriasis families when compared to the general population ( $\mathrm{OR}=1.8,95 \% \mathrm{Cl} 1.6-2.1, \mathrm{p}=0.002)$. There was a non-significant tendency towards a younger age of onset and overrepresentation of laryngeal cancer and leukaemia in psoriasis families. We found no major differences in the distribution of cancer susceptibility mutations among our cases and the healthy controls.

Conclusions: The results of our study suggest an increased risk of Hodgkin's lymphoma for male members of psoriasis families. Further studies are needed to confirm the findings and to evaluate whether or not the application of cancer surveillance protocols for Hodgkin's lymphoma, leukaemia and laryngeal cancer are justified in these families.

Keywords: Psoriasis vulgaris, Familial cancer risk

\section{Background}

Psoriasis is one of the most common skin disorders, and it is estimated that it affects $2-3 \%$ of the general Caucasian population [1]. Psoriasis is a chronic inflammatory skin disorder characterised by keratinocyte hyperproliferation and increased cutaneous blood flow induced via stimulation of tissue resident immune cells and a marked alteration of cytokine profiles [2]. Current evidence suggests that psoriasis is an immune-mediated disorder, and innovative therapies involved in the suppression of immune responses, such as T-cell-targeted agents and tumour

\footnotetext{
*Correspondence: debniak@pum.edu.pl

${ }^{2}$ Department of Genetics and Pathology, International Hereditary Cancer Center, Pomeranian Medical University, Połabska 4, 70-115, Szczecin, Poland Full list of author information is available at the end of the article
}

necrosis factor (TNF) inhibitors, have improved the outcome of the disease $[3,4]$. As judged by twin- and large population-based genetic studies, the disease seems to have a strong genetic component - disease concordance in monozygotic twins is at most $70 \%$, and the sibling recurrence risk of PsV has been estimated to range between 4 and 11 [5]. As of the publication of this writing, the molecular background of this disease remains unclear [6].

At present it is generally accepted that the disease is both multifactorial and genetically heterogeneous. GWAS studies identified several loci that are associated with psoriasis $[7,8]$. Recently 15 new susceptibility loci (which included candidate genes whose products are involved in innate host defense) have been revealed, increasing to 36 the number associated with psoriasis in European individuals [9].

\section{Biomed Central}

(c) 2013 Maleszka et al.; licensee BioMed Central Ltd. This is an Open Access article distributed under the terms of the Creative Commons Attribution License (http://creativecommons.org/licenses/by/2.0), which permits unrestricted use, distribution, and reproduction in any medium, provided the original work is properly cited. 
Follow-up studies of psoriasis patients point to an increased risk in the occurrence of malignancies at different sites of origin. Some reports suggest more common development of non-melanoma skin cancer among psoriasis patients [10-13]. Results of other studies point to the increased frequency of other neoplasms, such as cancers of the larynx, lung, colon, kidney, pancreas and non-Hodgkin's lymphoma [12,14-16]. Unfortunately, data from literature is not entirely consistent. According to Alderson and Clark, cancers of the skin, stomach or lung are not associated with psoriasis [17]. In a recent study of Finnish psoriasis patients, the estimated relative risk was higher for Hodgkin's and non-Hodgkin's lymphomas, squamous skin cancer and laryngeal cancers; the risk for other malignancies (such as colon, lung or kidney) was unchanged when compared to the general population [18].

Exposure to UVA and UVB (used in the treatment of psoriasis) most likely increases the risk of malignant melanoma $[19,20]$. According to Lee et al., melanoma and lymphoma are overrepresented among severe psoriasis patients [21]; however, the risk of malignant melanoma was reported to be diminished among psoriasis patients in other studies $[15,18]$.

Inconsistent data from literature can occur due to population stratification and/or complicated interpretation of evidence on the risk of cancer due to the small number of patients included in most series, precluding a full evaluation of rare neoplasms. Furthermore, the selection of patients in a clinical series might result in assessment of the effect of special types of therapies used in subsets of patients.

Herein we have investigated the risk of occurrence of malignancies of a different site of origin in a series of 517 psoriasis patients and their 1st degree relatives. We evaluated the tumour spectrum and age of diagnosis of cancers diagnosed in PsV families, as well as the observed and expected frequencies of malignancies.

Mutations/polymorphisms of many cancer susceptibility genes (such as BRCA1, CDKN2A, XPD, VDR, etc.) lead to tumour development. Some of these "cancer risk" gene alterations were also reported to be associated with psoriasis risk [22-24]. To evaluate the possible link between psoriasis and cancer, we examined the distribution of 17 mutations/polymorphisms in 10 known cancer susceptibility genes among patients and 517 matched healthy controls.

No such study has been published to date.

\section{Patients and methods \\ Patients}

The case group consisted of 517 (218 women and 299 men, mean age 42.9) unselected, consecutive patients with psoriasis vulgaris $(\mathrm{PsV})$ from North-western Poland.
Patients were recruited between 2010 and 2012 from outpatient clinics and hospital wards of the two participating dermatology departments: The Chair and Clinic of Skin and Venereal Diseases, PMU, Szczecin; and The Clinic of Dermatology and Venereology, PUMS, Poznań. Participation rates were over $80 \%$ for both centres. All patients were at least 18 years old, although the disease could have been diagnosed at an earlier age.

A detailed history of ancestry and clinical data concerning the age of the patient at diagnosis, the family history of psoriasis, smoking habits, personal cancer history and family cancer history was collected.

Controls consisted of 517 healthy adults, who were gender and age-matched case by case. All controls came from the West Pomerania region of Poland. Control samples were selected from a population-based study of 1.5 million individuals from West Pomerania who were enrolled in a study aimed at identifying familial aggregations of malignancies, which was recently performed by our centre. Individuals with psoriasis or a positive family history of psoriasis or cancer were excluded from the control group.

The study conformed to the Declaration of Helsinki, and all participants signed a form of consent prior to the donation of a blood sample. The study was approved by the institutional review board of the Pomeranian Medical University.

\section{Methods}

In the first stage of the study, we compared frequencies of malignant tumour occurrence and the age of the patient at diagnosis in PsV families against those of the general Polish population. We evaluated malignancies affecting probands and their $1^{\text {st }}$ degree relatives.

For statistical analyses, the Chi-Square test, U-test and odds ratio were utilised. Additional analyses performed in PsV families included the comparison of observed frequencies (OF) with expected frequencies (EF) and the relative risk (RR) of occurrence of malignancies at different sites of origin. OF and EF were calculated through evaluation of the total number of family members and affected cases in different age groups (range of 5 years) in PsV families in comparison to age-specific incidence rates in different age groups (range of 5 years) per 100,000 people. These calculations were done by site with individuals registered in the general population of Poland [25]. Bonferroni correction was used for multiple testing.

In the second stage of the study, we compared the prevalence of common alterations in DNA reported in literature to cancer susceptibility alterations among PsV patients, healthy controls and the general Polish population (data obtained from published reports). We genotyped founder BRCA1 mutations (5382insC, C61G, 
4153delA), common variants of XPD (D312M, K751Q), NOD2 (3020insC), CDKN2A (A148T), CHEK2 (CHIVS2, I157T), VDR (M1T), p53 (P72R), ATM (E1978X), MC1R (R160W, R151C, R163Q), MTHFR (A222V) and rs67 (rs6983267).

DNA samples were obtained from the peripheral blood of individuals. All SNPs were analysed by real-time PCR, using a LightCycler480 from Roche. The analyses were performed using the $\operatorname{TaqMan}(\mathrm{R})$ genotyping assay, which consists of sequence specific primers and oligonucleotide fluorescent labelled probes, enabling amplification of the examined fragments and further allele discrimination. Randomly selected probes were sequenced to confirm the results of real-time PCR.

Power calculations were done a posteriori based on the observed versus expected frequencies, the number of individuals analysed and the threshold p-value (after correction for multiple testing by Bonferroni). The significance threshold for the p-value was $0.05 / 24$ for analysis of the genetic markers, and in the case of analysis via the cancer site, the threshold was $0.05 / 19$ for women and $0.05 / 17$ for men (0.05 divided by the amount of hypotheses tested for the same group).

\section{Results}

Evaluation of the tumour spectrum revealed no statistically significant differences between proportions of malignancies observed in our PsV families when compared to the general population (Table 1). Analysis of the mean age of diagnosis (performed in our families for cancers affecting at least 5 cases) also revealed no significant differences between malignancies diagnosed among members of PsV families and the general population.

There was a tendency for an earlier appearance of leukaemia ( $\sim$ years), laryngeal cancer ( $\sim 6$ years) and melanoma (among males $\sim 6$ years) in PsV families (Table 1 ).

We observed 196 cancers among 3252 members of 517 psoriasis families. In comparison to the expected frequency (190 tumours), the difference was not significant $(\mathrm{p}=0.7931)$, neither for males $(\mathrm{p}=1.0)$ nor females $(\mathrm{p}=0.6519)$.

Table 1 Proportion and age at diagnosis of malignancies of different site of origin in PsV families and Polish population

\begin{tabular}{|c|c|c|c|c|c|c|c|c|}
\hline \multirow[t]{2}{*}{ Tumor site } & \multicolumn{2}{|c|}{ Males from psoriasis families } & \multicolumn{2}{|c|}{ Population (males)\# } & \multicolumn{2}{|c|}{$\begin{array}{l}\text { Females from psoriasis } \\
\text { families }\end{array}$} & \multicolumn{2}{|c|}{ Population (females)\# } \\
\hline & $\begin{array}{l}\text { Frequency } \\
\text { (\%) }\end{array}$ & $\begin{array}{l}\text { Mean age at } \\
\text { diagnosis (yrs) }\end{array}$ & $\begin{array}{l}\text { Frequency } \\
\qquad(\%)\end{array}$ & $\begin{array}{l}\text { Mean age at } \\
\text { diagnosis (yrs) }\end{array}$ & $\begin{array}{l}\text { Frequency } \\
\text { (\%) }\end{array}$ & $\begin{array}{l}\text { Mean age at } \\
\text { diagnosis (yrs) }\end{array}$ & $\begin{array}{l}\text { Frequency } \\
(\%)\end{array}$ & $\begin{array}{l}\text { Mean age at } \\
\text { diagnosis (yrs) }\end{array}$ \\
\hline Breast & 0 & $\mathrm{ND}^{\wedge} \wedge$ & 0,2 & 64,1 & 17,1 & 56,8 & 22,4 & 60,2 \\
\hline Lungs & 24,4 & 59,4 & 21,1 & 65,9 & 11,1 & 57,2 & 8,6 & 65,1 \\
\hline Colorectal & 14,1 & 60,6 & 12,4 & 67,2 & 7,7 & 64,8 & 10,1 & 68,3 \\
\hline Stomach & 4,7 & 65,6 & 4,9 & 66,4 & 1,7 & $\mathrm{ND}^{\wedge}$ & 2,7 & 68,6 \\
\hline Prostate & 14,1 & 66,1 & 13,2 & 70,1 & - & - & - & - \\
\hline Kidney & 3,8 & 67,5 & 4,1 & 63 & 5,1 & 63,3 & 2,8 & 65,2 \\
\hline Larynx & 7,5 & 56,5 & 2,7 & 62,4 & 0,8 & ND & 0,4 & 62,2 \\
\hline Melanoma & 1,9 & ND & 1,7 & 60,4 & 4,3 & 52,6 & 1,9 & 58,7 \\
\hline Skin & 1,9 & ND & 6,8 & 69,3 & 3,4 & ND & 7,5 & 70,2 \\
\hline Leukaemia & 4,7 & 52,6 & 2,2 & 56,9 & 4,3 & 58,2 & 1,9 & 62 \\
\hline Cervix & - & - & - & - & 6 & 58,5 & 4,4 & 56,8 \\
\hline Liver & 4,7 & 59,2 & 1,2 & 65,8 & 8,5 & 63,7 & 0,8 & 69,7 \\
\hline CNS & 5,7 & 54,2 & 2,4 & 55,3 & 6,8 & 61 & 2,3 & 59,3 \\
\hline Bladder & 1,9 & ND & 7,0 & 68,3 & 0 & ND & 2,0 & 68 \\
\hline Pancreas & 1,9 & ND & 2,3 & 64,7 & 2,6 & ND & 2,3 & 69,2 \\
\hline Uterus & - & - & - & - & 2,6 & 65,6 & 7,3 & 63,6 \\
\hline $\mathrm{FGT}^{*}$ & - & - & - & - & 9,4 & $48,6^{*}$ & 17,8 & $68,8^{*}$ \\
\hline $\begin{array}{l}\text { Hodgkin's } \\
\text { Disease }\end{array}$ & 1,9 & ND & 0,5 & 39,6 & 0 & ND & 0,5 & 37 \\
\hline NHLs & 0,9 & ND & 1,4 & & 0,8 & ND & 1,9 & \\
\hline
\end{tabular}

\#- general Polish population, according to data published by National Cancer Registry (Zatoński 2010).

$\wedge$ ND-not done-mean age was calculated for malignancies affecting at least 5 individuals.

${ }^{*}$ - $p<0.05$, statistically significant, FGT-female genital tract- site of origin could not be determined more precisely. 
A statistical comparison of the observed and expected frequencies of cancers revealed a higher than expected occurrence of Hodgkin's lymphoma among males in PsV families when compared to the general population $(\mathrm{OR}=1.8,95 \% \mathrm{CI} 1.6-2.1, \mathrm{p}=0.002)$ (Table 2). There was a tendency, although non-significant, for melanoma overrepresentation among females from PsV families (OR=1.4, $\mathrm{p}=0.26$ ). A similar tendency for both males and females was observed for leukaemia $(\mathrm{OR}=1.4, \mathrm{p}=0.26)$ and laryngeal cancer $(\mathrm{OR}=1.3, \mathrm{p}>0.19)$.

Molecular examination of 17 mutations/polymorphisms in 10 cancer susceptibility genes in psoriasis patients and controls showed no major differences in distribution of cancer susceptibility mutations among PsV families and healthy controls (Table 3).

For analysis of genetic markers, the statistical power $a$ posteriori ranges between 0.12 in the most favourable case (marker rs6983267, variant GT) and 0.001 in the least favourable case (marker CHK2, variant IVS2+1G>A). Comparatively, for the most favourable case, the minimum sample size for a statistical power a priori of at least 0.7 should have been great than 1800 cases and an equivalent number of controls.

For analysis by cancer site, the statistical power $a$ posteriori ranges between 0.17 in the most favourable case (female lung cancer) and 0.0015 in the least favourable case (several types of cancer, e.g. male liver cancer). Comparatively, for the most favourable case, the minimum sample size for a statistical power a priori of at least 0.7 should have been greater than 12400 first degree relatives.

\section{Discussion}

Tumour spectrum and the age of the patient at diagnosis of malignancies of different sites of origin observed in our PsV families and in the general population were similar. However, there was a higher than expected frequency of the occurrence of Hodgkin's lymphoma in males from PsV families. We also observed a tendency towards overrepresentation of leukaemia and laryngeal cancer among PsV families.

Our findings are consistent with the results of a follow up study of Swedish hospitalised psoriasis patients, which point to a significant excess of Hodgkin's lymphoma and cancers of the upper aerodigestive tract [26]. An increased risk of Hodgkin's lymphoma and laryngeal cancer has also been reported for Finnish hospitalised patients [18]. The association of leukaemia and psoriasis is not well-documented. There are a series of case reports of leukaemia developing in psoriasis patients treated with immunosuppressive drugs, such as cyclosporine, methotrexate or etanercept [27-31]. Our results support the theory that psoriasis is not associated with an increased risk of NHL overall or of any NHL subtype [32], although
Table 2 Expected and observed frequencies, related risk of occurrence of malignancies of different site of origin in psoriasis families

\begin{tabular}{|c|c|c|c|c|}
\hline Tumor site & Gender & $\begin{array}{l}\text { Observed } \\
\text { cases }\end{array}$ & $\begin{array}{l}\text { Expected } \\
\text { cases }\end{array}$ & $\begin{array}{l}\text { Relative risk } \\
\text { (RR, Cl 95\%), p }\end{array}$ \\
\hline Breast & Females & 20 & 21 & $1.0, p=0,8736$ \\
\hline \multirow[t]{2}{*}{ Lungs } & Males & 26 & 26 & $1.0, p=1.0$ \\
\hline & Females & 13 & 9 & $1,2, p=0,3891$ \\
\hline \multirow[t]{2}{*}{ Colorectal } & Males & 15 & 16 & 1.0, $p=0,8553$ \\
\hline & Females & 9 & 11 & $0.9, p=0,6518$ \\
\hline \multirow[t]{2}{*}{ Stomach } & Males & 5 & 6 & $0.9, p=0,7618$ \\
\hline & Females & 4 & 10 & $0.6, p=0,1066$ \\
\hline \multirow[t]{2}{*}{ Liver } & Males & 1 & 1 & 1.0, $p=1.0$ \\
\hline & Females & 2 & 1 & $1.3, p=0,5632$ \\
\hline \multirow[t]{2}{*}{ Melanoma } & Males & 2 & 2 & $1.0, p=1.0$ \\
\hline & Females & 5 & 2 & 1.4, $p=0,2554$ \\
\hline \multirow[t]{2}{*}{ Kidney } & Males & 4 & 5 & $0.9, p=0,7378$ \\
\hline & Females & 6 & 4 & $1.2, p=0,5253$ \\
\hline Prostate & Males & 15 & 16 & $1.0, p=0,8553$ \\
\hline \multirow[t]{2}{*}{ Larynx } & Males & 6 & 3 & $1.3, p=0,3152$ \\
\hline & Females & 1 & 0,5 & $1.3, p=0,1964$ \\
\hline \multirow[t]{2}{*}{ CNS } & Males & 3 & 2 & $1.2, p=0,6539$ \\
\hline & Females & 4 & 2 & $1.4, p=0,4130$ \\
\hline \multirow[t]{2}{*}{ Leukaemia } & Males & 5 & 2 & $1.4, p=0,2552$ \\
\hline & Females & 5 & 2 & 1.4, $p=0,2554$ \\
\hline \multirow{2}{*}{$\begin{array}{l}\text { Hodgkin } \\
\text { Lymphoma }\end{array}$} & Males & 2 & 0,2 & $1.8, p=0.002^{*}$ \\
\hline & Females & 0 & 0 & - \\
\hline \multirow[t]{2}{*}{ Bones } & Males & 1 & 1 & $1.0, p=1.0$ \\
\hline & Females & 2 & 1 & $1.3, p=0,5632$ \\
\hline \multirow[t]{2}{*}{ Bladder } & Males & 1 & 1 & 1.0, $p=1.0$ \\
\hline & Females & 0 & 2 & $P=0,1569$ \\
\hline \multirow[t]{2}{*}{$\mathrm{NHL}$} & Males & 1 & 1 & $1.0, p=1.0$ \\
\hline & Females & 1 & 1 & $1.0, p=1.0$ \\
\hline \multirow[t]{2}{*}{ Pancreas } & Males & 2 & 3 & $0.8, p=0,6539$ \\
\hline & Females & 3 & 3 & 1.0, $p=1.0$ \\
\hline Uterus & Females & 3 & 7 & $0.6, p=0,2039$ \\
\hline Ovary & Females & 4 & 5 & $0.9, p=0,7379$ \\
\hline \multirow[t]{2}{*}{ Thyroid } & Males & 0 & 0.5 & $P=0.0523$ \\
\hline & Females & 2 & 2 & 1.0, $p=1.0$ \\
\hline Cervix & Females & 5 & 4 & $1.1, p=0,7379$ \\
\hline \multirow{2}{*}{$\begin{array}{l}\text { Non-melanoma } \\
\text { skin cancer }\end{array}$} & Males & 9 & 9 & $1.0, p=1.0$ \\
\hline & Females & 9 & 8 & $1.0, p=0,8069$ \\
\hline
\end{tabular}

*p-after Bonferroni correction.

there are some reports suggesting that such an association exists $[16,18]$. We observed a non-significant tendency of melanoma overrepresentation among females from PsV families. This insignificant correlation does 
Table 3 Prevalence of the examined mutations/polymorphisms among PsV cases and healthy controls

\begin{tabular}{|c|c|c|c|c|}
\hline Gene (Mutation) & Cases & Controls & $\mathrm{p}$ & OR \\
\hline \multirow[t]{2}{*}{ BRCA1 (ex20)(ex5-300) } & $2 / 507$ 0,39\% & 1) $/ 5100,20 \%$ & 0,5597 & 2,016 \\
\hline & $1 / 507$ 0,20\% & 0 & 0,3156 & 3,024 \\
\hline CHK2 (1157T) & $22(+) / 5034,37 \%$ & $28(+) / 5075,52 \%$ & 0,4000 & 0,7824 \\
\hline CHK2 (IVS2+1G>A) & $2(+) / 5030,40 \%$ & $2(+) / 507$ 0,39\% & 0,9937 & 1,008 \\
\hline NOD2 (3020insC) & $43(+) / 5008,60 \%$ & $41(+) / 5108,04 \%$ & 0,7469 & 1,076 \\
\hline \multirow[t]{2}{*}{ XPD 936 (D312M) CT Tा } & $200 / 491$ 40,73\% & 199 / 493 40,37\% & 0,9064 & 1,015 \\
\hline & 127 / $49125,87 \%$ & 114 / $49323,12 \%$ & 0,3173 & 1,160 \\
\hline \multirow[t]{2}{*}{ XPD 2253 (K751Q) GT GG } & $240 / 50347,71 \%$ & $240 / 51047,06 \%$ & 0,8347 & 1,027 \\
\hline & 82 / 503 16,30\% & 89 / $51017,45 \%$ & 0,6255 & 0,9213 \\
\hline \multirow[t]{2}{*}{ MC1R (R151C) CT TT } & $33 / 4287,71 \%$ & 35 / $5016,99 \%$ & 0,6727 & 1,112 \\
\hline & $0 / 4280 \%$ & $2 / 5010,40 \%$ & 0,1907 & 0,2331 \\
\hline \multirow[t]{2}{*}{ MC1R (V60L) GT TT } & $50 / 44811,16 \%$ & 63 / $51012,35 \%$ & 0,5681 & 0,8914 \\
\hline & $1 / 4480,22 \%$ & $6 / 5101,18 \%$ & 0,0839 & 0,1879 \\
\hline \multirow[t]{2}{*}{ MC1R (R163Q) AG AA } & $30 / 435$ 6,90\% & $37 / 5017,38 \%$ & 0,7724 & 0,9289 \\
\hline & $1 / 4350,23 \%$ & $2 / 5010,40 \%$ & 0,6476 & 0,5749 \\
\hline \multirow[t]{2}{*}{ VDR (M1T) AG AA } & $240 / 49048,98 \%$ & 252 / $50849,61 \%$ & 0,8431 & 0,9752 \\
\hline & 99 / $49020,20 \%$ & 99 / 508 19,49\% & 0,7768 & 1,046 \\
\hline CDKN2A (A148T) & $26(+) / 5015,19 \%$ & $28(+) / 5115,48 \%$ & 0,8375 & 0,9442 \\
\hline \multirow[t]{2}{*}{ p53 (P72R) CG CC } & $192 / 503$ 38,17\% & 195 / 512 38,09\% & 0,9778 & 1,004 \\
\hline & 34 / 503 6,76\% & 33 / 512 6,44\% & 0,8403 & 1,052 \\
\hline \multirow[t]{2}{*}{ rs6983267 GT TT } & $261 / 50152,10 \%$ & 234 / 509 45,97\% & 0,0516 & 1,278 \\
\hline & $119 / 50123,75 \%$ & $123 / 50924,17 \%$ & 0,8779 & 0,9776 \\
\hline ATM (E198X) & $0(+) / 4990 \%$ & $0(+) / 5080 \%$ & - & - \\
\hline \multirow[t]{2}{*}{ MTHFR (A222V) CT TT } & $223 / 48845,70 \%$ & 227 / 499 45,49\% & 0,9483 & 1,008 \\
\hline & 47 / 488 9,63\% & 44 / 499 8,82\% & 0,6587 & 1,102 \\
\hline
\end{tabular}

not clarify the inconsistent data from literature regarding the association of melanoma with psoriasis. We show that the risk of melanoma is not significantly increased for individuals from PsV families.

Due to the relatively small numbers of cases, both type 1 and 2 statistical errors cannot be excluded; the results thus need to be verified by examination of a larger series of patients. The current study lacks the statistical power to confirm if the absence of observed association is due to a true lack of association or rather due to an insufficient sample size. The current research should be considered only as an exploratory study attempting to reveal interesting tendencies worthy of in-depth analysis at a later stage.

Assessing the risk of cancer as a single outcome revealed no statistically significant association between psoriasis and cancer. It indicates that the common tumours (such as cancers of the breast, prostate, lung or colon) constituting the majority of neoplasms are not strongly linked with psoriasis. However, it does not exclude a moderate association for rare malignancies.
The results of molecular genotyping of mutations/ polymorphisms present in cancer susceptibility genes revealed no differences in the prevalence of the examined alterations between cases and controls. It seems that none of the examined alterations in DNA are associated with psoriasis. This is the first such study evaluating any linkage between the BRCA1 gene (predisposing to breast and ovarian cancer), CHEK2 gene (cancers of the prostate, thyroid, breast, colon, stomach), MC1R gene (melanoma, non-melanoma skin cancers), ATM gene (cancers of the breast, pancreas, thyroid) and the XPD gene (melanoma, oesophageal squamous cell carcinoma, cancers of the lung and breast) with psoriasis. Our results are consistent with current data in literature, suggesting that NOD2 (colorectal and breast cancer), p53 (cancers of the cervix, bladder, prostate, breast) and MTHFR (oesophageal and cervical cancers) might not be susceptibility genes for psoriasis [33-36]. Our findings support the thesis that the VDR gene (predisposing to melanoma and breast cancer) does not show a robust and reproducible association with the risk of psoriasis 
[37]. Since this theory conflicts with other findings $[22,23,38]$, any association that may exist is likely to be weak and potentially restricted to specific populations. Down-expression of another cancer susceptibility gene, CDKN2A (predisposing to melanoma, cancers of the pancreas, breast and lung), led to speculation that the gene may have a role in the pathogenesis of psoriasis [24]. Our findings do not support this thesis.

According to many follow-up studies, there is an increased risk of the most common human malignancy, basal cell cancer (BCC), among psoriasis patients [10-13]. In a recent study, genetic susceptibility to basal cell carcinoma (BCC) among Danish psoriatic patients was investigated and confirmed previous reports that XPD may predispose to BCC [39-41]. Interestingly, we did not observe any excess of non-melanoma skin cancers in our families and found no association of XPD common variants with psoriasis. This lack of association suggests that the risk is restricted to individuals treated with phototherapy, which constituted only a small proportion of the individuals in our PsV families.

In conclusion, the results of our study indicate a moderate association between psoriasis and familial cancer risk. These results also suggest an increased risk of Hodgkin's lymphoma for male members of PsV families. Further studies are needed to confirm the findings and to evaluate whether or not cancer surveillance protocols are justified in these families.

\section{Competing interests}

Authors declare that they have no competing interests.

\section{Authors' contributions}

Conception and design: TD, RM. Acquiring, analysis and interpretation of data: TD, ES, MB, MR, JW, AM, KPS, LK, ZA; drafting the manuscript: TD, PSF, $\mathrm{RM}$; critical revision for important intelectual content: TD, RM; final approval: TD,ES, MB, MR, JW, AM, KPS, JL, LK, ZA, RM. All authors read and approved the final manuscript.

\section{Acknowledgement}

The study was funded by Polish National Science Centre (NCN) grant number NN402371938.

\section{Author details \\ 'Department of Dermatology and Venerology, Pomeranian Medical University, Szczecin, Poland. ²Department of Genetics and Pathology, International Hereditary Cancer Center, Pomeranian Medical University, Połabska 4, 70-115, Szczecin, Poland. ${ }^{3}$ Regional Hospital, Koszalin, Poland. ${ }^{4}$ Clinic of Dermatology and Venerology, Poznan University of Medical Science, Szczecin, Poland.}

Received: 30 April 2013 Accepted: 29 May 2013

Published: 28 June 2013

\section{References}

1. Lebwohl M: Psoriasis. Lancet 2003, 361:1197-204.

2. Balderas J, Bowcock AM: The genetics of psoriasis: a complex disorder of the skin and immune system. Hum Mol Genet 1998, 7:1537-1545.

3. Krueger JG: The immunologic basis for the treatment of psoriasis with new biologic agents. J Am Acad Dermatol 2002, 46:1-23.

4. Gottlieb AB: Psoriasis: emerging therapeutic strategies. Nat Rev Drug Discov 2005, 4:19-34
5. Henseler T: The genetics of psoriasis. J Am Acad Dermatol 1997, 37:1-11.

6. Elder JT, Nair RP, Guo SW, Henseler T, Christophers E, Voorhees JJ: The genetics of psoriasis. Arch Dermatol 1994, 130:216-224.

7. Ellinghaus $E$, Ellinghaus D, Stuart PE, Nair RP, Debrus S, Raelson JV, et al: Genome-wide association study identifies a psoriasis susceptibility locus at TRAF3IP2. Nat Genet 2010, 42:991-5.

8. Genetic Analysis of Psoriasis Consortium \& the Wellcome Trust Case Control Consortium 2, Strange A, Capon F, Spencer CC, Knight J, Weale ME, Allen MH, Barton A, Band G, Bellenguez C, Bergboer JG, Blackwell JM, Bramon E, Bumpstead SJ, Casas JP, Cork MJ, Corvin A, Deloukas P, Dilthey A,

Duncanson A, Edkins S, Estivill X, Fitzgerald O, Freeman C, Giardina E, Gray E, Hofer A, Hüffmeier U, Hunt SE, Irvine AD, et al: A genome-wide association study identifies new psoriasis susceptibility loci and an interaction between HLA-C and ERAP1. Nat Genet 2010, 42:985-990.

9. Tsoi LC, Spain SL, Knight J, Ellinghaus E, Stuart PE, Capon F, Ding J, Li Y, Tejasvi T, Gudjonsson JE, Kang HM, Allen MH, McManus R, Novelli G, Samuelsson L, Schalkwijk J, Ståhle M, Burden AD, Smith CH, Cork MJ, Estivill X, Bowcock AM, Krueger GG, Weger W, Worthington J, Tazi-Ahnini R, Nestle FO, Hayday A, Hoffmann P, Winkelmann J, et al: Identification of 15 new psoriasis susceptibility loci highlights the role of innate immunity. Nat Genet 2012, 44(12):1341-1348.

10. Stern RS, Vakeva LH: Noncutaneous malignant tumors in the PUVA follow-up study: 1975-1996. J Invest Dermatol 1997, 108:897-900.

11. Stern RS, Liebman EJ, Vakeva L: Oral psoralen and ultraviolet-A light (PUVA) treatment of psoriasis and persistent risk of nonmelanoma skin cancer. PUVA Follow-up Study. J Natl Cancer Inst 1998, 90:1278-1284.

12. Frentz $\mathrm{G}$, Olsen $\mathrm{JH}$ : Malignant tumours and psoriasis: a follow-up study. Br J Dermatol 1999, 140:237-242.

13. Lindelof $B$, Sigurgeirsson $B$, Tegner $E$, Larko $O$, Johannesson $A$, Berne $B$, Ljunggren B, Andersson T, Molin L, Nylander-Lundqvist E, Emtestam Li: PUVA and cancer risk: the Swedish follow-up study. Br J Dermatol 1999, 141:108-112.

14. Olsen $\mathrm{JH}$, Mùller $\mathrm{H}$, Frentz $\mathrm{G}$ : Malignant tumors in patients with psoriasis. J Am Acad Dermatol 1992, 27:716-722.

15. Boffetta $P$, Gridley G, Lindelöf B: Cancer risk in a population-based cohort of patients hospitalized for psoriasis in Sweden. J Invest Dermatol 2001, 117(6):1531-1537.

16. Lan CC, Ko YC, Yu HS, Li WC, Wu CS, Lu YW, Yang YH, Chen GS: Psoriatic patients with diabetes are prone to develop digestive organ cancers: a population-based study in Taiwan. J Dermatol Sci 2012, 68(2):82-88.

17. Alderson MR, Clarke JA: Cancer incidence in patients with psoriasis. $\mathrm{Br} J$ Cancer 1983, 47(6):857-859.

18. Hannuksela-Svahn A, Pukkala E, Läärä E, Poikolainen K, Karvonen J: Psoriasis, its treatment, and cancer in a cohort of Finnish patients. $J$ Invest Dermatol 2000, 114(3):587-590.

19. Stern RS, Nichols KT, Vakeva LH: Malignant melanoma in patients treated for psoriasis with methoxsalen (psoralen) and ultraviolet a radiation (puva). New England J Med 1997, 336:1041-1045.

20. Stern RS: The risk of melanoma in association with longterm exposure to PUVA. J Am Acad Dermatol 2001, 44:755-761.

21. Lee MS, Lin RY, Chang YT, Lai MS: The risk of developing non-melanoma skin cancer, lymphoma and melanoma in patients with psoriasis in Taiwan: a 10-year, population-based cohort study. Int I Dermatol 2012, 51(12):1454-1460.

22. Liu JL, Zhang SQ, Zeng HM: Apal, Bsml, Fokl and Taql polymorphisms in the vitamin $\mathrm{D}$ receptor (VDR) gene and the risk of psoriasis: a metaanalysis. J Eur Acad Dermatol Venereol. in press.

23. Lee YH, Choi SJ, Ji JD, Song GG: Vitamin D receptor Apal, Taql, Bsml, and Fokl polymorphisms and psoriasis susceptibility: a meta-analysis. Mol Biol Rep 2012, 39(6):6471-6478.

24. Lee SK, Jeon EK, Kim YJ, Seo SH, Kim CD, Lim JS, Lee JH: A global gene expression analysis of the peripheral blood mononuclear cells reveals the gene expression signature in psoriasis. Ann Dermatol 2009, 21(3):237-242

25. Wojciechowska U, Didkowska J, Zatoński W: Cancer in Poland in 2010. Warsaw: The Maria-Skłodowska-Curie Memorial Cancer Center, Department of Epidemiology and cancer Prevention, Polish National Cancer Registry; 2012

26. Ji J, Shu X, Sundquist K, Sundquist J, Hemminki K: Cancer risk in hospitalized psoriasis patients: a follow-up study in Sweden. $\mathrm{Br} J$ Cancer 2009, 100(9):1499-1502. 
27. Koga M, Koga K, Isitsuka K, Imafuku S, Nakayama J: Coexistence of adult T-cell leukaemia /lymphoma and psoriasis treated with cyclosporine. Eur J Dermatol 2012, 22(2):275-276.

28. Knudson RM, Tefferi A, Pittelkow MR, Davis MD: Development of myelodysplastic syndrome evolving to acute myeloid leukemia in a patient receiving etanercept for psoriasis. J Am Acad Dermatol 2011, 65(3):673-674.

29. Dasanu CA, Bauer F, Ichim TE, Vyas D, Ek K, Alexandrescu DT: Rapidly fatal acute ATLL emerging after methotrexate therapy for disseminated psoriasis. Clin Lymphoma Myeloma Leuk 2012, 12(1):76-78.

30. Bachmeyer C, Thiolière B, Khosrotehrani K, Cattan E: Acute myelogenous leukemia in a patient receiving etanercept for psoriasis. $J$ Am Acad Dermatol 2007, 56(1):169-170.

31. Watabe H, Soma Y, Obara W, Murakami N, Kawase A, Mizukami T, Koike M, Shibuya Y, Mizoguchi M: Adult T-cell lymphoma/leukaemia developing in a patient with psoriasis treated with long-term cyclosporine. Acta Derm Venereol 2006, 86(2):184-185.

32. Smedby KE, Hjalgrim H, Askling J, Chang ET, Gregersen H, PorwitMacDonald A, Sundström C, Akerman M, Melbye M, Glimelius B, Adami HO: Autoimmune and chronic inflammatory disorders and risk of nonHodgkin lymphoma by subtype. J Natl Cancer Inst 2006, 98(1):51-60

33. Borgiani P, Vallo L, D'Apice MR, Giardina E, Pucci S, Capon F, Nisticò S, Chimenti S, Pallone F, Novelli G: Exclusion of CARD15/NOD2 as a candidate susceptibility gene to psoriasis in the Italian population. Eur $J$ Dermatol 2002, 12(6):540-542.

34. Plant D, Lear J, Marsland A, Worthington J, Griffiths CE: CARD15/NOD2 single nucleotide polymorphisms do not confer susceptibility to type I psoriasis. Br J Dermatol 2004, 151(3):675-678.

35. Assmann G, Wagner AD, Monika M, Pfoehler C, Pfreundschuh M, Tilgen W, Roemer K: Single-nucleotide polymorphisms p53 G72C and Mdm2 T309G in patients with psoriasis, psoriatic arthritis, and SAPHO syndrome. Rheumatol Int 2010, 30(10):1273-1276.

36. Weger W, Hofer A, Stanger O, Wolf P, El-Shabrawi Y, Renner W, Kerl H, Salmhofer W: The methylenetetrahydrofolate reductase $677 \mathrm{C}>\mathrm{T}$ gene polymorphism is not associated with chronic plaque psoriasis. Exp Dermatol 2008, 17(9):748-751.

37. Stefanic M, Rucevic I, Barisic-Drusko V: Meta-analysis of vitamin D receptor polymorphisms and psoriasis risk. Int I Dermatol. in press.

38. Halsall JA, Osborne JE, Pringle JH, Hutchinson PE: Vitamin D receptor gene polymorphisms, particularly the novel A-1012G promoter polymorphism, are associated with vitamin D3 responsiveness and non-familial susceptibility in psoriasis. Pharmacogenet Genomics 2005, 15(5):349-355.

39. Yin J, Vogel U, Gerdes LU, Dybdahl M, Bolund L, Nexø BA: Twelve single nucleotide polymorphisms on chromosome 19q13.2-13.3: linkage disequilibria and associations with basal cell carcinoma in Danish psoriatic patients. Biochem Genet 2003, 41(1-2):27-37.

40. Vogel U, Hedayati M, Dybdahl M, Grossman L, Nexø BA: Polymorphisms of the DNA repair gene XPD: correlations with risk of basal cell carcinoma revisited. Carcinogenesis. 2001, 22(6):899-904. Erratum in: Carcinogenesis 2002, 23(2):373.

41. Dybdahl M, Vogel U, Frentz G, Wallin H, Nexø BA: Polymorphisms in the DNA repair gene XPD: correlations with risk and age at onset of basal cell carcinoma. Cancer Epidemiol Biomarkers Prev 1999, 8(1):77-81.

\section{Submit your next manuscript to BioMed Central and take full advantage of:}

- Convenient online submission

- Thorough peer review

- No space constraints or color figure charges

- Immediate publication on acceptance

- Inclusion in PubMed, CAS, Scopus and Google Scholar

- Research which is freely available for redistribution 